\title{
Upaya Meningkatkan Prestasi Belajar Ilmu Pengetahuan Alam Materi Sistem Reproduksi pada Manusia Dengan Menerapkan Strategi Pembelajaran Point Counterpoin dengan Media Gambar pada Siswa Kelas IX 1 SMP Negeri 1 Praya Tahun pelajaran 2019/2020
}

\author{
Sumardayati \\ Guru Mata Pelajaran IPA SMP Negeri 1 Praya Kabupaten Lombok Tengah
}

\begin{abstract}
Abstrak. Penelitian ini berdasarkan permasalahan: (a) Apakah pembelajaran CounterPoint berpengaruh terhadap hasil Belajar Ilmu Pengetahuan Alam? (b) Seberapa tinggi tingkat penguasaan materi pelajaran Ilmu Pengetahuan Alam dengan diterapkannya metode pembelajaran strategi pembelajaran point counterpoin? Tujuan dari penelitian ini adalah: (a) Untuk mengungkap pengaruh pembelajaran Counter Point terhadap hasil Belajar Ilmu Pengetahuan Alam. (b) Ingin mengetahui seberapa jauh pemahaman dan penguasaan mata pelajaran Ilmu Pengetahuan Alam setelah diterapkannya pembelajaran Counter Point Penelitian ini menggunakan penelitian tindakan (action research) sebanyak tiga putaran. Setiap putaran terdiri dari empat tahap yaitu: rancangan, kegiatan dan pengamatan, refleksi, dan refisi. Sasaran penelitian ini adalah siswa Kelas 91 . Data yang diperoleh berupa hasil tes formatif, lembar observasi kegiatan belajar mengajar. Dari hasil analis didapatkan bahwa prestasi belajar siswa mengalami peningkatan dari siklus I sampai siklus III yaitu, siklus I (56\%), siklus II (80\%), siklus III (91\%). Simpulan dari penelitian ini adalah metode strategi pembelajaran counterpoin dapat berpengaruh positif terhadap motivasi belajar Siswa Kelas IX.1 SMP Negeri 1 Praya, serta model pembelajaran ini dapat digunakan sebagai salah satu alternative Ilmu Pengetahuan Alam .
\end{abstract}

\section{Kata Kunci: Ilmu Pengetahuan Alam, Strategi Pembelajaran Point Counterpoin}

\section{PENDAHULUAN}

Gambaran guru yang kompeten menjadi sangat berat dan luas. Tidak dapat dihindarkan bahwa syarat yang mendasar bagi seorang guru yang kompeten perlu diselaraskan dengan tuntutan dan kemajuan zaman tersebut. Guru saat ini harus mengerti akan hakikat gejala-gajala yang dihadapi, nilai-nilai yang diteruskan kepada anak yang memang belum mantap. Dalam masa transisi ini guru harus lebih kreatif dan inovatif, apalagi menghadapi zaman komputer pada masa sekarang ini. Berarti kompetensi guru telah dituntut dengan pengetahuan, keterampilan dan sikap yang baru.

Didasarkan pada Peraturan Pemerintah No 19 tahun 2005 tentang Standar Nasional Pendidikan, pada Pasal 19 ayat 1 dinyatakan bahwa: Proses Pembelajaran Pada Satuan Pendidikan diselenggarakan secara interaktif, inspiratif, menyenangkan, menantang, memotivasi peserta didik untuk berpartisipasi aktif, serta memberikan ruang yang cukup bagi prakarsa, kreativitas, dan kemandirian sesuai dengan bakat, minat, dan perkembangan fisik serta psikologis peserta didik.

Di lembaga pendidikan seperti di SMP Negeri 1 Praya Proses belajar mengajar, juga memberikan ruang cukup luas pada maslaah kreatifitas. Hal ini dapat dilihat dari proses belajar mengajar yang sudah mulai ada fariasinya. Dari media pembelaajran yang diberikan oleh guru sampai minat belajar siswa yang sudah terbangun. Akan tetapi, hal itu tidaklah cukup. Karena media pembelajaran juga harus seimbang dengan metode pembelajaran guru di dalam kelas. Guru harus pandai dalam memenejemen kelas, rekayasa pendidikan dan inovatif pendidikan.

Oleh karena itu, diperlukan sinkronisasi antar beberapa hal tersebut. Guru bisa memberikan media pembelajran yang sesuai dengan metode pembelajarannya. Dari situ, maka didapati adanya formulasi yang tepat 
untuk mengatasi masalah prestasi belajar di SMP Negeri 1 Praya

Harapan peneliti tersebut, akan peneliti terapkan pada penelitian ini. Output yang dihasilkan adalah ketuntasan siswa dalam pembelajran beberapa siklus. Disitulah peneliti akan mengetahui, setiap perkembangan dalam setiap siklusnya.

Untuk itu, dalam proses pembelajaran ini peneliti mempunyai terobosan atau berani menerapkan metode, strategi yang baru, sehingga kelas tidak terlihat fakum dan peserta didik tidak merasa bosan. Dengan menerapkan metode baru, siswa bisa semangat dalam belajar, aktif dalam kelas baik bertanya, memberikan ide/gagasan, dan lebih berinteraksi lagi dengan lingkungannya (sesama siswa, guru maupun masyarakat).

Untuk menimbulkan motivasi yang akan mendorong anak agar dapat berbuat sesuatu dalam mencapai tujuan belajarnya, maka diperlukan adanya peningkatan aktivitas belajar anak. Sedangkan untuk meningkatkan aktivitas belajar anak, maka perlu adanya motivasi-motivasi guru yang sekiranya peserta didik menjadi semangat dan giat dalam belajar. Salah satu alternatif yang penulis tawarkan adalah dengan menerapkan Pengertian strategi pembelajaran point counterpoin pada saat kegiatan belajar berlangsung sehingga hasil pendidikan yang sesuai dapat terwujud dengan harapan kita.

Dengan latar belakang tersebut, maka penulis akhirnya mengambil sebuah judul" Upaya Meningkatkan Prestasi Belajar Ilmu Pengetahuan Alam Materi Sistem Reproduksi pada Manusia Dengan Menerapkan Strategi Pembelajaran Point Counterpoin dengan media gambar Pada Siswa Kelas IX 1 SMP Negeri 1 Praya Tahun pelajaran 2019/2020"

\section{Rumusan Masalah}

Bertitik tolak dari latar belakang diatas maka penulis merumuskan permasalahnnya sebagi berikut:

1. Bagaimanakah peningkatan prestasi belajar Ilmu Pengetahuan Alam dengan diterapkannya pembelajaran strategi pembelajaran point counterpoint dengan media gambar pada siswa Kelas IX.1 SMP Negeri 1 Praya?
2. Bagaimanakah pengaruh pembelajaran strategi pembelajaran point counterpoint terhadap motivasi belajar Ilmu Pengetahuan Alam pada siswa Kelas IX1 SMP Negeri 1 Praya?

\section{Tujuan Penelitian}

Sesuai dengan permasalahan di atas, penelitian ini bertujuan untuk:

1. Ingin mengetahui peningkatan prestasi belajar Ilmu Pengetahuan Alam setelah diterapkannya pembelajaran strategi pembelajaran point counterpoint dengan media gambar pada siswa Kelas IX1 SMP Negeri 1 Praya

2. Ingin mengetahui pengaruh motivasi belajar Ilmu Pengetahuan Alam setelah diterapkan pembelajaran strategi pembelajaran point counterpoint pada siswa Kelas IX 1 SMP Negeri 1 Praya?

\section{Manfaat Penelitan}

Adapun maksud penulis mengadakan penelitian ini diharapkan dapat berguna sebagai:

1. Menambah pengetahuan dan wawasan penulis tentang peranan guru Ilmu Pengetahuan Alam dalam meningkatkan pemahaman siswa belajar Ilmu Pengetahuan Alam.

2. Sumbangan pemikiran bagi guru Ilmu Pengetahuan Alam dalam mengajar dan meningkatkan pemahaman siswa belajar Ilmu Pengetahuan Alam .

\section{KAJIAN PUSTAKA}

\section{Tinjauan Tentang Strategi Pembelajaran Point Counterpoint}

Point counterpoint artinya saling beradu pendapat sesuai dengan perspektif, strategi ini merupakan satu teknik untuk merangsang diskusi dan mendapatkan pemahaman yang lebih mendalam tentang berbagai isu kompleks

Pengertian strategi pembelajaran point counterpoin Terdapat berbagai pendapat tentang strategi pembelajaran diantaranya:
a. Kozna
(1989)
secara
umum
menjelaskan bahwa strategi
pembelajaran dapat diartikan sebagai setiap kegiatan yang dipilih, yaitu yang dapat memberikan fasilitas atau bantuan kepada peserta didik menuju 
tercapainya tujuan pembelajaran tertentu

b. Gerlach dan ely (1980) menjelaskan bahwa strategi pembelajaran merupakan cara-cara yang dipilih untuk menyampaikan metode pembelajaran dalam lingkungan pembelajaran tertentu.

c. Dick dan carey (1990) menjelaskan bahwa strategi pembelajaran terdiri atas seluruh komponen materi pembelajaran dan prosedur atau tahapan kegiatan belajar yang atau digunakan oleh guru dalam rangka membentu peserta didik mencapai tujuan pembelajaran tertentu

d. Gropper (1990) mengatakan bahwa strategi pembelajaran merupakan pemilihan atas berbagai jenis latihan tertentu yang sesuai dengan tujuan pembelajaran yang ingin dicapai.

Memerhatikan beberapa pengertian strategi pembelajaran diatas, dapat disimpulkan bahwa strategi pembelajaran merupakan cara-cara yang akan dipilih dan digunakan oleh seorang pengajar untuk menyampakan materi pembelajaran sehingga akan memudahkan peserta didik menerima dan memahami materi pembelajara, yang pada akirnya tujuan pembelajaran dapat dikuasainya diakhir kegiatan belajar

Tujuan penerapan strategi point counterpoint adalah untuk melatih peserta didik agar mencari argumentasi yang kuat dalam memecahkan suatu masalah yang actual di masyarakat sesuai dengan posisi yang diperankan. Jadi strategi point counterpoint adalah suatu cara dalam proses pembelajaran yang memberikan kesempatan pada siswa untuk aktif berargumen (mengajukan ide-ide, gagasan) dari persoalan yang muncul atau sengaja dimunculkan dalam pembelajaran sesuai dengan aturanaturan yang ada.

\section{Langkah-langkah strategi point- counterpoint}

Langkah-langkah strategi pointcounterpoint a). Guru memilih satu permasalahan yang mempunyai dua perspektif atau lebih. b). Guru membagi kelas menjadi beberapa kelompok sesuai dengan perspektif (pandangan yang ada). c). Pastikan masing-masing kelompok duduk terpisah. d). Guru memberi kesempatan kepada siswa untuk berdiskusi menyiapkan argument. e). Guru memberikan kesempatan pada salah satu kelompok untuk mulai berdebat, setelah itu undang anggota kelompok lain untuk menyampaikan pandangan yang berbeda. f). Guru mereview, dan memberikan kesimpulan dengan membandingkan isu-isu yang terlihat secara utuh.

\section{Tinjauan Tentang Keaktifan Belajar} Siswa

Pengertian Keaktifan Belajar

Keaktifan berasal dari kata dasar aktif yang mendapat awalan ke- dan akhiran-an. Aktif menurut Akhmad Sudrajad adalah, bahwa dalam proses pemberlajaran guru harus menciptakan suasana sedemikian rupa sehingga siswa aktif bertanya, mempertanyakan, dan mengemukakan gagasan.

Sedangkan menurut Sriyono dkk, keaktifan sebagai usaha guru dalam mengaktifkan murid-muridnya baik dari segi jasmani maupun rohani pada waktu proses pembelajaran sedang berlangsung.

Belajar seringkali didefinisikan sebagai perubahan yang secara relatif berlangsung lama pada masa berikutnya yang diperoleh kemudian dari pengalaman-pengalaman. Sebagian orang beranggapan belajar adalah semata-mata mengumpulkan atau menghafalkan fakta-fakta yang tersaji dalam bentuk informasi atau materi pelajaran. Adapula yang memandang belajar sebagai latihan belaka seperti tampak pada latihan membaca dan menulis.

\section{Materi Pembelajaran}

Sistem Reproduksi pada Manusia

Pada awalnya, manusia berasal dari satu sel, selanjutnya sel tersebut mengalami pembelahan secara terus menerus, sehingga pada saat dewasa manusia memiliki sekitar 200 triliun sel. Sel-sel tersebut mengalami perubahan bentuk dan fungsi. Sel-sel yang memiliki bentuk dan fungsi yang sama akan 
bergabung menjadi suatu kesatuan untuk membentuk suatu jaringan.

\section{METODE PENELITIAN}

\section{Bentuk Penelitian Tindakan}

Penelitian ini merupakan penelitian tindakan (action research), karena penelitian dilakukan untuk memecahkan masalah pembelajaran di kelas. Penelitian ini juga termasuk penelitian deskriptif, sebab menggambarkan bagaimana suatu teknik pembelajaran diterapkan dan bagaimana hasil yang diinginkan dapat dicapai.

Menurut Oja dan Sumarjan (dalam Titik Sugiarti, 1997: 8) mengelompokkan penelitian tindakan menjadi empat macam yaitu, (a) guru sebagai peneliti, (b) penelitian tindakan kolaboratif; (c) simultan terintegratif; (d) administrasi sosial eksperimental.

Dalam penelitian tindakan ini menggunakan bentuk guru sebagai peneliti, penanggung jawab penuh penelitian ini adalah guru. Tujuan utama dari penelitian tindakan ini adalah untuk meningkatkan hasil pembelajaran di kelas dimana guru secara penuh terlibat dalam penelitian mulai dari perencanaan, tindakan, pengamatan, dan refleksi.

\section{Tempat, Waktu dan Subyek Penelitian}

Penelitian ini bertempat di Kelas IX.1

SMP Negeri 1 Praya pada bulan September semester ganjil tahun pelajaran 2019/2020 dengan pokok bahasan Sistem Reproduksi Manusia

\section{Rancangan Penelitian}

Menurut pengertiannya, penelitian tindakan adalah penelitian tentang hal-hal yang terjadi di sekelompok masyarakat atau sasaran, dan hasilnya langsung dapat dikenakan pada masyarakat yang bersangkutan (Arikunto, Suharsimi, 2002: 82). Ciri atau karakteristik utama dalam penelitian tindakan adalah adanya partisipasi dan kolaborasi antara peneliti dengan anggota kelompok sasaran. Penelitian tindakan adalah satu strategi pemecahan masalah yang memanfaatkan tindakan nyata dalam bentuk proses pengembangan invovatif yang dicoba sambil jalan dalam mendeteksi dan memecahkan masalah. Dalam prosesnya, pihak-pihakyang terlibat dalam kegiatan tersebut dapat mendukung satu sama lain.

Adapun langkah-dalam penelitian tindakan kelas ini adalah seperti gambar berikut.

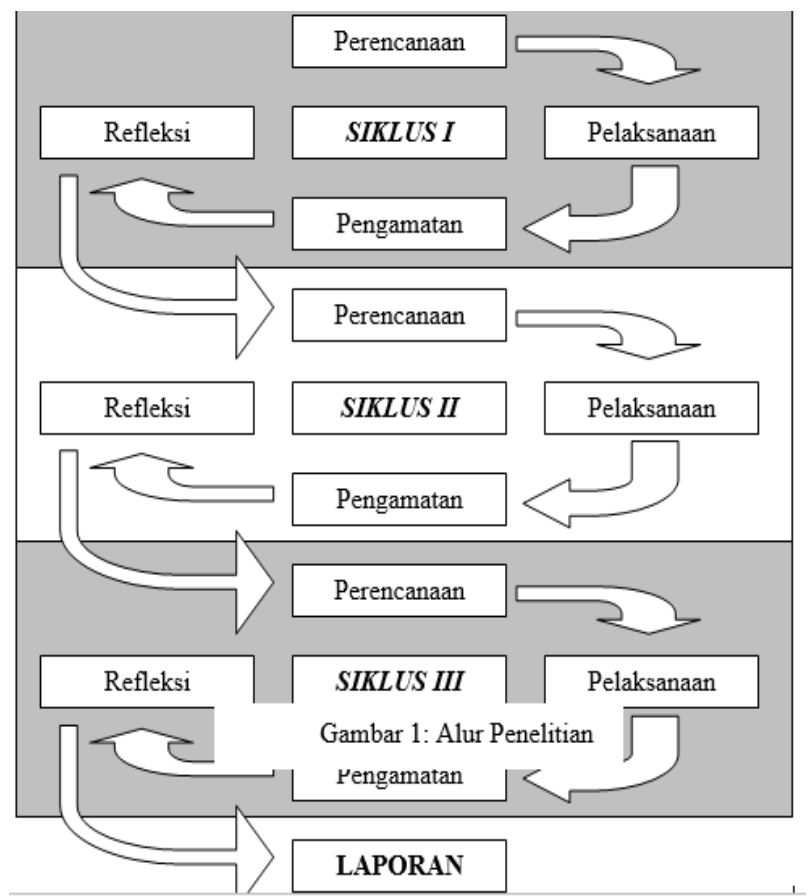

Gambar 1: Alur Penelitian Tindakan Kelas

\section{Instrumen Penelitian}

Instrumen yang digunakan dalam penelitian ini terdiri dari: Silabus, Rencana Pelajaran (RP), Lembar Kegiatan Siswa, Tes formatif; Tes ini disusun berdasarkan tujuan pembelajaran yang akan dicapai, digunakan untuk mengukur kemampuan pemahaman konsep Ilmu Pengetahuan Alam pada pokok bahasan Sistem Reproduksi pada Manusia untuk produksi, komunikasi dan transportasi. Tes formatif ini diberikan setiap akhir putaran. Bentuk soal yang diberikan adalah pilihan guru (objektif). Sebelumnya soal-soal ini berjumlah 40 soal yang telah diujicoba, kemudian penulis mengadakan analisis butir soal tes yang telah diuji validitas dan reliabilitas pada tiap soal. Analisis ini digunakan untuk memilih soal yang baik dan memenuhi syarat digunakan untuk mengambil data. Langkah-langkah analisis butir soal adalah sebagai berikut:

\section{Validitas Tes}

Validitas butir soal atau validitas item digunakan untuk mengetahui tingkat kevalidan masing-masing butir soal. 
Sehingga dapat ditentukan butir soal yang gagal dan yang diterima. Tingkat kevalidan ini dapat dihitung dengan korelasi Product Moment:

$$
r_{x y}=\frac{N \sum X Y-\left(\sum X\right)\left(\sum Y\right)}{\sqrt{\left.\left\{N \sum X^{2}-\left(\sum X\right)^{2}\right) N \sum Y^{2}-\left(\sum Y\right)^{2}\right\}}}
$$

(Suharsimi Arikunto, 2001: 72)

Dengan:

$\mathrm{r}_{\mathrm{xy}}$ : Koefisien korelasi product moment

$\mathrm{N}$ : Jumlah peserta tes

$\Sigma \mathrm{Y}:$ Jumlah skor total

$\Sigma \mathrm{X}:$ Jumlah skor butir soal

$\Sigma X^{2}$ : Jumlah kuadrat skor butir soal

$\Sigma X Y$ : Jumlah hasil kali skor butir soal

\section{Reliabilitas}

Reliabilitas butir soal dalam penelitian ini menggunakan rumus belah dua sebagai berikut:

$$
r_{11}=\frac{2 r_{1 / 21 / 2}}{\left(1+r_{1 / 21 / 2}\right)}
$$

(Suharsimi Arikunto, 2001: 93)

Dengan:

$\mathrm{r}_{11}$ : Koefisien reliabilitas yang sudah disesuaikan

$\mathbf{r}_{1 / 21 / 2}$ : Korelasi antara skor-skor setiap belahan tes

Kriteria reliabilitas tes jika harga $r_{11}$ dari perhitungan lebih besar dari harga $\mathrm{r}$ pada tabel product moment maka tes tersebut reliabel.

\section{Taraf Kesukaran}

Bilangan yang menunjukkan sukar dan mudahnya suatu soal adalah indeks kesukaran. Rumus yang digunakan untuk menentukan taraf kesukaran adalah:

$$
P=\frac{B}{J_{S}}
$$

(Suharsimi Arikunto, 2001: 208)

Dengan:

P: Indeks kesukaran

B : Banyak siswa yang menjawab soal dengan benar

Js : Jumlah seluruh siswa peserta tes

Kriteria untuk menentukan indeks kesukaran soal adalah sebagai berikut:

Soal dengan $\mathrm{P}=0,000$ sampai 0,300 adalah sukar

Soal dengan $\mathrm{P}=0,301$ sampai 0,700 adalah sedang
Soal dengan $\mathrm{P}=0,701$ sampai 1,000 adalah mudah

\section{Daya Pembeda}

Daya pembeda soal adalah kemampuan suatu soal untuk membedakan antara siswa yang berkemampuan tinggi dengan siswa yang berkemampuan rendah. Angka yang menunjukkan besarnya daya pembeda desebut indeks diskriminasi. Rumus yang digunakan untuk menghitung indeks diskriminasi adalah sebagai berikut:

$$
D=\frac{B_{A}}{J_{A}}-\frac{B_{B}}{J_{B}}=P_{A}-P_{B}
$$

(Suharsimi Arikunto, 2001: 211)

\section{Dimana:}

D : Indeks diskriminasi

$\mathrm{B}_{\mathrm{A}}$ : Banyak peserta kelompok atas yang menjawab dengan benar

$\mathrm{B}_{\mathrm{B}}$ : Banyak peserta kelompok bawah yang menjawab dengan benar

$\mathrm{J}_{\mathrm{A}} \quad$ : Jumlah peserta kelompok atas

$\mathrm{J}_{\mathrm{B}}$ : Jumlah peserta kelompok bawah

$$
P_{A}=\frac{B_{A}}{J_{A}}=
$$

Proporsi peserta kelompok atas yang menjawab benar.

$$
P_{B}=\frac{B_{B}}{J_{B}}=
$$

Proporsi peserta kelompok bawah yang menjawab benar

Kriteria yang digunakan untuk menentukan daya pembeda butir soal sebagai berikut:

Soal dengan $D=0,000$ sampai 0,200 adalah jelek

Soal dengan $\mathrm{D}=0,201$ sampai 0,400 adalah cukup

Soal dengan $\mathrm{D}=0,401$ sampai 0,700 adalah baik

Soal dengan $\mathrm{D}=0,701$ sampai 1,000 adalah sangat baik

\section{Metode Pengumpulan Data}

Data-data yang diperlukan dalam penelitian ini diperoleh melalui observasi pengolahan belajar aktif, observasi aktivitas siswa dan guru, dan tes formatif.

\section{Teknik Analisis Data}

Untuk mengetahui keefektivan suatu metode dalam kegiatan pembelajaran perlu 
diadakan analisa data. Pada penelitian ini menggunakan teknik analisis deskriptif kualitatif, yaitu suatu metode penelitian yang bersifat menggambarkan kenyataan atau fakta sesuai dengan data yang diperoleh dengan tujuan untuk mengetahui prestasi belajar yang dicapai siswa juga untuk memperoleh respon siswa terhadap kegiatan pembelajaran serta aktivitas siswa selama proses pembelajaran.

Untuk menganalisis tingkat keberhasilan atau persentase keberhasilan siswa setelah proses belajar mengajar setiap putarannya dilakukan dengan cara memberikan evaluasi berupa soal tes tertulis pada setiap akhir putaran.

Analisis ini dihitung dengan menggunakan statistik sederhana yaitu:

Untuk menilai ulangan atau tes formatif

Peneliti melakukan penjumlahan nilai yang diperoleh siswa, yang selanjutnya dibagi dengan jumlah siswa yang ada di kelas tersebut sehingga diperoleh rata-rata tes formatif dapat dirumuskan:

$$
\bar{X}=\frac{\sum X}{\sum N}
$$

Dengan

$: \bar{X} \quad=$ Nilai rata-rata

$\Sigma X=$ Jumlah semua nilai siswa

$\Sigma \mathrm{N}=$ Jumlah siswa

Untuk ketuntasan belajar

Ada dua kategori ketuntasan belajar yaitu secara perorangan dan secara klasikal. Berdasarkan petunjuk pelaksanaan belajar mengajar kurikulum 1994 (Depdikbud, 1994), yaitu seorang siswa telah tuntas belajar bila telah mencapai skor $65 \%$ atau nilai 65 , dan kelas disebut tuntas belajar bila di kelas tersebut terdapat $85 \%$ yang telah mencapai daya serap lebih dari atau sama dengan $65 \%$.

\section{HASIL DAN PEMBAHASAN}

Data penelitian yang diperoleh berupa hasil uji coba item butir soal, data observasi berupa pengamatan pengelolaan pembelajaran strategi pembelajaran point counterpoin dan pengamatan aktivitas siswa dan guru pada akhir pembelajaran, dan data tes formatif siswa pada setiap siklus.
Data hasil uji coba item butir soal digunakan untuk mendapatkan tes yang betul-betul mewakili apa yang diinginkan. Data ini selanjutnya dianalisis tingkat validitas, reliabilitas, taraf kesukaran, dan daya pembeda.

Data lembar observasi diambil dari dua pengamatan yaitu data pengamatan pengelolaan pembelajaran strategi pembelajaran point counterpoin yang digunakan untuk mengetahui pengaruh penerapan model pembelajaran strategi pembelajaran point counterpoin dalam meningkatkan prestasi belajar siswa dan data pengamatan aktivitas siswa dan guru.

Data tes formatif untuk mengetahui peningkatan prestasi belajar siswa setelah diterapkan pembelajaran strategi pembelajaran point counterpoin.

\section{Analisis Item Butir Soal}

Sebelum melaksanakan pengambilan data melalui instrument penelitian berupa tes dan mendapatkan tes yang baik, maka data tes tersebut diuji dan dianalisis. Uji coba dilakukan pada siswa di luar sasaran penelitian. Analisis tes yang dilakukan meliputi:

\section{Validitas}

Validitas butir soal dimaksudkan untuk mengetahui kelayakan tes sehingga dapat digunakan sebagai instrument dalam penelitian ini. Dari perhitungan 46 soal diperoleh 16 soal tidak valid dan 30 soal valid. Hasil dari validits soal-soal dirangkum dalam tabel di bawah ini.

Tabel 4.1. Soal Valid dan Tidak Valid Tes Formatif Siswa

\begin{tabular}{|l|l|}
\hline Soal Valid & Soal Tidak Valid \\
\hline $1,2,3,4,7,9,10,11,12,13,14,17,19,21,23$, & $5,6,8,15,16,18,20,22$, \\
$25,26,27,28,22,30,36,37,38,39,41,42,43$, & $24,31,32,33,34,35,40$, \\
44,45 & 46 \\
\hline
\end{tabular}

\section{Reliabilitas}

Soal-soal yang telah memenuhi syarat validitas diuji reliabilitasnya. Dari hasil perhitungan diperoleh koefisien reliabilitas $\mathrm{r}_{11}$ sebesar 0, 554. Harga ini lebih besar dari harga $\mathrm{r}$ product moment. Untuk jumlah siswa $(\mathrm{N}=28)$ dengan $\mathrm{r}(95 \%)=0,374$. Dengan demikian soal-soal tes yang digunakan telah memenuhi syarat reliabilitas. 


\section{Taraf Kesukaran (P)}

Taraf kesukaran digunakan untuk mengetahui tingkat kesukaran soal. Hasil analisis menunjukkan dari 46 soal yang diuji terdapat: 20 soal mudah, 15 soal sedang, 11 soal sukar

\section{Daya Pembeda}

Analisis daya pembeda dilakukan untuk mengetahui kemampuan soal dalam membedakan siswa yang berkemampuan tinggi dengan siswa yang berkemampuan rendah. Dari hasil analisis daya pembeda diperoleh soal yang berkteriteria jelek sebanyak 16 soal, berkriteria cukup 20 soal, berkriteria baik 10 soal. Dengan demikian soal-soal tes yang digunakan telah memenuhi syara-syarat validitas, reliabilitas, taraf kesukaran, dan daya pembeda.

\section{Analisis Data Penelitian Persiklus}

Siklus I

Tahap Perencanaan

Pada tahap ini peneliti mempersiapkan perangkat pembelajaran yang terdiri dari rencana pelajaran 1 , soal tes formatif 1 dan alat-alat pengajaran yang mendukung.

Tahap Kegiatan dan Pelaksanaan

Pelaksanaan kegiatan belajar mengajar untuk siklus I dilaksanakan pada tanggal 6 agustus 2019 di Kelas IX1 dengan jumlah siswa 32 siswa. Dalam hal ini peneliti bertindak sebagai guru. Adapun proses belajar mengajar mengacu pada rencana pelajaran yang telah dipersiapkan. Pengamatan (observasi) dilaksanakan bersamaan dengan pelaksaaan belajar mengajar

Pada akhir proses belajar mengajar siswa diberi tes formatif I dengan tujuan untuk mengetahui tingkat keberhasilan siswa dalam proses belajar mengajar yang telah dilakukan. Adapun data hasil penelitian pada siklus I adalah sebagai berikut:

Dari hasil analisis data dapat dijelaskan bahwa dengan menerapkan pembelajaran strategi pembelajaran point counterpoin diperoleh nilai rata-rata prestasi belajar siswa adalah 66 dan ketuntasan belajar mencapai $59 \%$ atau ada 19 siswa dari 32 siswa sudah tuntas belajar. Hasil tersebut menunjukkan bahwa pada siklus pertama secara klasikal siswa belum tuntas belajar, karena siswa yang memperoleh nilai $\geq 65$ hanya sebesar $59 \%$ lebih kecil dari persentase ketuntasan yang dikehendaki yaitu sebesar $85 \%$. Hal ini disebabkan karena siswa masih baru dan asing terhadap metode baru yang diterapkan dalam proses belajar mengajar.

\section{Refleksi}

Dalam pelaksanaan kegiatan belajar mengajar diperoleh informasi dari hasil pengamatan sebagai berikut:

1) Guru kurang baik dalam memotivasi siswa dan dalam menyampaikan tujuan pembelajaran

2) Guru kurang baik dalam pengelolaan waktu

3) Siswa kurang begitu antusias selama pembelajaran berlangsung.

\section{Refisi}

Pelaksanaan kegiatan belajar mengajar pada siklus I ini masih terdapat kekurangan, sehingga perlu adanya refisi untuk dilakukan pada siklus berikutnya.

1) Guru perlu lebih terampil dalam memotivasi siswa dan lebih jelas dalam menyampaikan tujuan pembelajaran. Dimana siswa diajak untuk terlibat langsung dalam setiap kegiatan yang akan dilakukan.

2) Guru perlu mendistribusikan waktu secara baik dengan menambahkan informasiinformasi yang dirasa perlu dan memberi catatan

3) Guru harus lebih terampil dan bersemangat dalam memotivasi siswa sehingga siswa bisa lebih antusias.

Siklus II

Tahap perencanaan

Pada tahap ini peneliti mempersiapkan perangkat pembelajaran yang terdiri dari rencana pelajaran 2 , soal tes formatif II dan alat-alat pengajaran yang mendukung.

Tahap kegiatan dan pelaksanaan

Pelaksanaan kegiatan belajar mengajar untuk siklus II dilaksanakan pada 20 Agustus 2019 di Kelas IX 1 dengan jumlah siswa 32 siswa. Dalam hal ini peneliti bertindak sebagai guru. Adapun proses belajar mengajar mengacu pada rencana pelajaran dengan memperhatikan revisi pada siklus I, sehingga kesalah atau kekurangan pada siklus I tidak terulang lagi pada siklus II. 
Pengamatan (observasi) dilaksanakan bersamaan dengan pelaksanaan belajar mengajar.

Pada akhir proses belajar mengajar siswa diberi tes formatif II dengan tujuan untuk mengetahui tingkat keberhasilan siswa dalam proses belajar mengajar yang telah dilakukan. Instrument yang digunakan adalah tes formatif II. Adapun data hasil penelitian pada siklus II adalah sebagai berikut.

Dari analisadata diperoleh nilai ratarata prestasi belajar siswa adalah 77 dan ketuntasan belajar mencapai $72 \%$ atau ada 23 siswa dari 32 siswa sudah tuntas belajar. Hasil ini menunjukkan bahwa pada siklus II ini ketuntasan belajar secara klasikal telah mengalami peningkatan sedikit lebih baik dari siklus I. Adanya peningkatan hasil belajar siswa ini karena siswa mambantu siswa yang kurang mampu dalam mata pelajaran yang mereka pelajari. Disamping itu adanya kemampuan guru yang mulai meningkat dalam prose belajar mengajar.

\section{Refleksi}

Dalam pelaksanaan kegiatan belajar diperoleh informasi dari hasil pengamatan sebagai berikut:, Memotivasi siswa, Membimbing siswa merumuskan kesimpulan/menemukan konsep , Pengelolaan waktu

\section{Revisi Rancangan}

Pelaksanaan kegiatan belajar pada siklus II ini masih terdapat kekurangankekurangan. Maka perlu adanya revisi untuk dilaksanakan pada siklus II antara lain:

1) Guru dalam memotivasi siswa hendaknya dapat membuat siswa lebih termotivasi selama proses belajar mengajar berlangsung.

2) Guru harus lebih dekat dengan siswa sehingga tidak ada perasaan takut dalam diri siswa baik untuk mengemukakan pendapat atau bertanya.

3) Guru harus lebih sabar dalam membimbing siswa merumuskan kesimpulan/menemukan konsep.

4) Guru harus mendistribusikan waktu secara baik sehingga kegiatan pembelajaran dapat berjalan sesuai dengan yang diharapkan.
5) Guru sebaiknya menambah lebih banyak contoh soal dan memberi soal-soal latihan pada siswa untuk dikerjakan pada setiap kegiatan belajar mengajar.

\section{Siklus III}

Tahap Perencanaan

Pada tahap ini peneliti mempersiapkan perangkat pembelajaran yang terdiri dari rencana pelajaran 3 , soal tes formatif 3 dan alat-alat pengajaran yang mendukung.

\section{Tahap kegiatan dan pengamatan}

Pelaksanaan kegiatan belajar mengajar untuk siklus III dilaksanakan pada tanggal 27 Agustus 2019 di Kelas IX 1 dengan jumlah siswa 32 siswa. Dalam hal ini peneliti bertindak sebagai guru. Adapun proses belajar mengajar mengacu pada rencana pelajaran dengan memperhatikan revisi pada siklus II, sehingga kesalahan atau kekurangan pada siklus II tidak terulang lagi pada siklus III. Pengamatan (observasi) dilaksanakan bersamaan dengan pelaksanaan belajar mengajar.

Pada akhir proses belajar mengajar siswa diberi tes formatif III dengan tujuan untuk mengetahui tingkat keberhasilan siswa dalam proses belajar mengajar yang telah dilakukan. Instrumen yang digunakan adalah tes formatif III. Adapun data hasil penelitian pada siklus III adalah sebagai berikut:

Berdasarkan pengolahan nilai diperoleh nilai rata-rata tes formatif sebesar 80 dan dari 32 siswa yang telah tuntas sebanyak 29 siswa dan 3 siswa belum mencapai ketuntasan belajar. Maka secara klasikal ketuntasan belajar yang telah tercapai sebesar 90\% (termasuk kategori tuntas). Hasil pada siklus III ini mengalami peningkatan lebih baik dari siklus II. Adanya peningkatan hasil belajar pada siklus III ini dipengaruhi oleh adanya peningkatan kemampuan siswa dalam mempelajari materi pelajaran yang telah diterapkan selama ini serta ada tanggung jawab kelompok dari siswa yang lebih mampu untuk mengajari temannya kurang mampu.

\section{Refleksi}

Pada tahap ini akah dikaji apa yang telah terlaksana dengan baik maupun yang masih kurang baik dalam proses belajar 
mengajar dengan penerapan pembelajaran strategi pembelajaran point counterpoin. Dari data-data yang telah diperoleh dapat duraikan sebagai berikut:

1) Selama proses belajar mengajar guru telah melaksanakan semua pembelajaran dengan baik. Meskipun ada beberapa aspek yang belum sempurna, tetapi persentase pelaksanaannya untuk masing-masing aspek cukup besar.

2) Berdasarkan data hasil pengamatan diketahui bahwa siswa aktif selama proses belajar berlangsung.

3) Kekurangan pada siklus-siklus sebelumnya sudah mengalami perbaikan dan peningkatan sehingga menjadi lebih baik.

4) Hasil belajar siswsa pada siklus III mencapai ketuntasan.

\section{Revisi Pelaksanaan}

Pada siklus III guru telah menerapkan pembelajaran strategi pembelajaran point counterpoin dengan baik dan dilihat dari aktivitas siswa serta hasil belajar siswa pelaksanaan proses belajar mengajar sudah berjalan dengan baik. Maka tidak diperlukan revisi terlalu banyak, tetapi yang perlu diperhatikan untuk tindakah selanjutnya adalah memaksimalkan dan mempertahankan apa yang telah ada dengan tujuan agar pada pelaksanaan proses belajar mengajar selanjutnya penerapan pembelajaran strategi pembelajaran point counterpoin dapat meningkatkan proses belajar mengajar sehingga tujuan pembelajaran dapat tercapai.

\section{PEMBAHASAN}

\section{Ketuntasan Hasil belajar Siswa}

Melalui hasil peneilitian ini menunjukkan bahwa pembelajaran strategi pembelajaran point counterpoin memiliki dampak positif dalam meningkatkan prestasi belajar siswa. Hal ini dapat dilihat dari semakin mantapnya pemahaman dan penguasaan siswa terhadap materi yang telah disampaikan guru selama ini (ketuntasan belajar meningkat dari sklus I, II, dan III) yaitu masing-masing 59\%, 72\%, dan 90\% Pada siklus III ketuntasan belajar siswa secara klasikal telah tercapai.
Kemampuan Guru dalam Mengelola Pembelajaran

Berdasarkan analisis data, diperoleh aktivitas siswa dalam proses pembelajaran strategi pembelajaran point counterpoin dalam setiap siklus mengalami peningkatan. Hal ini berdampak positif terhadap peningkatan prestasi belajar siswa dan penguasaan materi pelajaran yang telah diterima selama ini, yaitu dapat ditunjukkan dengan meningkatnya nilai rata-rata siswa pada setiap siklus yang terus mengalami peningkatan.

\section{Aktivitas Guru dan Siswa Dalam Pembelajaran}

Berdasarkan analisis data, diperoleh aktivitas siswa dalam proses pembelajaran Ilmu Pengetahuan Alam dengan pembelajaran strategi pembelajaran point counterpoin yang paling dominan adalah, mendengarkan/memperhatikan penjelasan guru, dan diskusi antar siswa/antara siswa dengan guru. Jadi dapat dikatakan bahwa aktivitas isiwa dapat dikategorikan aktif.

Sedangkan untuk aktivitas guru selama pembelajaran telah melaksanakan langkah-langkah pembelajaran strategi pembelajaran point counterpoin dengan baik. Hal ini terlihat dari aktivitas guru yang muncul di antaranya aktivitas membimbing dan mengamati siswa dalam mengerjakan kegiatan, menjelaskan materi yang tidak dimengerti siswa, memberi umpan balik/evaluasi/tanya jawab dimana prosentase untuk aktivitas di atas cukup besar.

\section{PENUTUP}

Dari hasil kegiatan pembelajaran yang telah dilakukan selama tiga siklus, dan berdasarkan seluruh pembahasan serta analisis yang telah dilakukan dapat disimpulkan sebagai berikut:

1. pembelajaran strategi pembelajaran point counterpoin memiliki dampak positif dalam meningkatkan prestasi belajar Ilmu Pengetahuan Alam siswa yang ditandai dengan peningkatan ketuntasan belajar siswa dalam setiap siklus, yaitu siklus I (56\%) siklus II (80\%) dan siklus III (91\%).

2. Penerapan pembelajaran strategi pembelajaran point counterpoin 
mempunyai pengaruh positif, yaitu dapat meningkatkan motivasi belajar siswa dalam belajar Ilmu Pengetahuan Alam, hal ini ditunjukan dengan antusias siswa yang menyatakan bahwa siswa tertarik dan berminat dengan pembelajaran strategi pembelajaran point counterpoin sehingga mereka menjadi termotivasi untuk belajar.

3. pembelajaran strategi pembelajaran point counterpoin memiliki dampak positif terhadap kerjasama antara siswa, hal ini ditunjukkan adanya tanggung jawab dalam kelompok dimana siswa yang lebih mampu mengajari temannya yang kurang mampu.

DAFTAR PUSTAKA

Arikunto, Suharsimi. Prosedur Penelitian Suatu Pendekatan Praktek. Yogyakarta: Rineka Cipta. 2002

Bradberry dan Graeaves. Taklukan Emosimu: The Way of Emotional Quotient for Your Better Life. Jogjakarta: Garailmu. 2018

Dimyati, Dr. Belajar dan Pembelajaran. Jakarta: Rinieka Cipta. 2002

Effendi, Agus. Revolusi Kecerdasan Abad 21. Bandung: Alfabeta. 2005

Goleman, Daniel. Emotional Intelligence, mengapa EI lebih penting daripasa IQ. Jakarta: PT Gramedia Pustaka Umum. 2007

Hasan, Iqbal. Analisis Data Penelitian dengan Statistik. Jakarta: Bumi Aksara. 2004

Jihad, Asep. Evaluasi Pemberlajaran. Yogyakarta: Multi Pressindo. 2018

Mulyasa. Menjadi Guru Professional. Bandung: Rosda karya. 2006

Nggermanto,Agus. Quantum Quotient ( kecerdasan quantum ): cara praktis melejitkan IQ, strategi pembelajaran point counterpoin, dan SQ. Bandung: Nuansa. 2008

Purwanto MPd, Dr. Evaluasi Hasil Belajar.Jogyakarta: Pustaka Pelajar. 2018

Purwanto, Drs. M. Ngalim, MP. Psikolgi Pendidikan. Bandung: Remaja Rosda Karya. 2000
Sirozi, M. Politik Pendidikan, Dinamika Hubungan antara Kepentingan Kekuasaan

dan Praktik Penyelengaraan Pendidikan. Jakarata: Raja GrafindoPersada. 2007

Syah M.Ed, Muhibbin. Psikologi Belajar. Jakarta: Logos Wacana Ilmu. 2001

Sudijono, Prof. Drs. Anas. Pengantar Statistik Pendidikan. Jakarta: PT Raja GrafindoPersada. 2006

Sugiono. Metode Penelitian Pendidikan. Bandung: Alfabeta. 2007

Sukmadinata, Prof. Dr. Nana Syaodih. Landasan Psikologi Proses Pendidikan.Bandung: PT Remaja Rosda Karya. 2005

Supranto, J. Statistik Teori dan Aplikasi jilid 11. jakarta: Erlangga. 2001

Suryabrata, Sumadi. Psikologi Pendidikan. Jakarta : Raja Grafindo Persada. 1998

Thomas R. Hoerr, Buku Kerja Multiple Intelligence. Bandung: Mizan. 2007

Tyas, Esthi Endah Ayuning. Cerdas Emosional dengan Musik. Yogyakarta: ArtiBumi Intaran. 2008

Yamin,Moh. Manajemen Mutu Kurikulum Pendidikan. Jogyakarta: Diva Press. 2018

Undang-Undang RI N. 14 tahun 2005 GURU DAN DOSEN dan UndangundangRI No. 2003 tahun 2003 tentang SISDIKNAS. Wacana ntelektual. 2006

Uno, Dr. Hamzah B. M.pd. Teori Motivasi dan Pengukuranaya: analisis bidangpendidikan. Jakarta: Bumi Aksara. 2008 